\title{
An assessment of lesions in bay scallops Argopecten irradians attributed to Perkinsus karlssoni (Protozoa, Apicomplexa)
}

\author{
C. L. Goggin ${ }^{1}{ }^{\bullet}$, S. E. McGladdery ${ }^{2}$, S. K. Whyte ${ }^{3}$, R. J. Cawthorn ${ }^{3}$ \\ 'Department of Parasitology, The University of Queensland, Brisbane, Queensland 4072, Australia \\ ${ }^{2}$ Department of Fisheries and Oceans, Gulf Fisheries Centre, PO Box 5030, Moncton, New Brunswick, Canada E1C 9B6 \\ ${ }^{3}$ Department of Pathology and Microbiology, Atlantic Veterinary College, University of Prince Edward Island, 550 University Avenue. \\ Charlottetown, Prince Edward Island, Canada C1A 4 P3
}

\begin{abstract}
Lesions found in bay scallops Argopecten irradians imported into Atlantic Canada for culture were attributed to a parasite Perkinsus karlssoni. It appears, however, that stages from several organisms were combined to create the life cycle of $P$. karlssoni. The ultrastructure of the agent in lesions of bay scallops is not documented adequately to diagnose affinities to the genus Perkinsus. Furthermore, there was discrepancy as to whether $P$. karlssoni enlarged in fluid thioglycollate medium, and the shape and structure of the prezoosporangia as well as the movement and life span of the zoospores were not consistent with the genus Perkinsus. $P$. karlssoni cannot be considered as a species of Perkinsus
\end{abstract}

KEY WORDS: Perkinsus karlssoni - Apicomplexa - Parasite Bay scallop $\cdot$ Argopecten irradians

Perkinsus is a genus of protistan parasite which infects and kills marine molluscs. It has been found in more than 30 species of molluscs around the world (Goggin \& Lester 1987, Perkins 1988). Four species have been described: $P$. marinus from eastern oysters Crassostrea virginica in America (Mackin et al. 1950, Levine 1978); $P$. atlanticus from clams Ruditapes decussatus in Portugal (Azevedo 1989); P. olseni from abalone Haliotis rubra in Australia (Lester \& Davis 1981); and P. karlssoni from bay scallops Argopecten irradians in eastern Canada and adjacent United States (McGladdery et al. 1991, McGladdery et al. 1993). There are significant differences, however, between $P$. karlssoni and the other 3 described species of Perkinsus. P. karlssoni is used hereafter as a matter of convenience with the recognition that there may be

- Present address: CSIRO Division of Fisheries, GPO Box 1538, Hobart, Tasmania 7001, Australia.

E-mail: louise.goggin@ml.csiro.au more than 1 organism associated with this name which may later be described outside the genus Perkinsus.

Bay scallops Argopecten irradians imported into Canada for culture in 1979 and 1980 suffered heavy post-spawning mortalities. McGladdery et al. (1991) described 'swirl' lesions from the bay scallops which they attributed to the parasite Perkinsus karlssoni. 'Swirl' lesions were most numerous in post-spawning scallops. Bay scallops, however, usually die after spawning and $P$. karlssoni was not associated with the pathogenesis. The 'swirl' lesion found in A. irradians is a generalised response to a foreign agent and is not diagnostic of an infection by parasites in the genus Perkinsus. P. karlssoni which were healthy when preserved have not been seen under the electron microscope. The organisms identified as P. karlssoni in electron micrographs published by Whyte et al. (1994) (Fig. 18a, b) are dead organisms encapsulated by ceroid and do not resemble Perkinsus.

In histological sections, the meront of species of Perkinsus is distinguished by a large eccentric vacuole which sometimes contains a vacuoplast. A vacuole was rarely observed in $P$. karlssoni, but a dense basophilic body was found next to the nucleus which could be equivalent to the vacuoplast of $P$. marinus (McGladdery et al. 1991). The basophilic body of $P$. karlssoni, however, was not contained in a large eccentric vacuole, which makes this association unlikely. Furthermore, the presence of a basophilic body does not diagnose a Perkinsus spp. because the vacuoplast can be either basophilic or eosinophilic in P. marinus (Mackin et al. 1950) or slightly eosinophilic (when present) in $P$. olseni (Lester \& Davis 1981).

Perkinsus karlssoni differs from described species of Perkinsus in other ways. P. karlssoni was not recognised by an antibody raised against the meront of $P$. 
marinus that binds to the 3 other described species of Perkinsus in histological sections (Dungan \& Roberson 1993). The 'swirl' lesion which surrounds P. karlssoni does not account for the failure of the immunological test because the antibody recognised Perkinsus sp. in similar lesions in clams Mya arenaria (C. Dungan pers. comm.). These results suggest that P. karlssoni does not belong to the genus Perkinsus.

Perkinsus infections are diagnosed by incubating host tissues in fluid thioglycollate medium (FTM) for several days. The parasites enlarge and can be stained with Lugol's iodine after incubation (Ray 1966). Blueblack spheres were found in tissues of Argopecten irradians from Canada using this procedure (McGladdery et al. 1991, Whyte et al, 1994). McGladdery et a!. (1991) reported that meronts increased from $4.3-23.11 \mu \mathrm{m}$ to reach $80.0-138.3 \mu \mathrm{m}$ after incubation in FTM. Whyte et al. (1993a, p. 203) found, in contrast, that P. karlssoni did not swell in FTM. The difference in the results of the FTM test suggest that Whyte et al (1993a, b) isolated a different organism from that described by McGladdery et al. (1991). Indeed, the 'prezoosporangium' isolated from bay scallop tissues that had not been incubated in FTM (Whyte et al 1993a, Fig. 1b) does not belong to the genus Perkinsus. The organism has membranous plates or scales around the cell, multivesicular bodies in the cytoplasm and mitochondrial structure more closely resembling that of the thraustochytrids than that of Perkinsus spp. (see Moss 1985).

Meronts of Perkinsus spp. enlarge in FTM to form zoosporangia when released into seawater. Cells divide internally to produce thousands of motile zoospores which later escape through a discharge tube or plug on the surface of the zoosporangia. Prezoosporangia of Perkinsus spp. do not multiply when released in seawater. In contrast, bay scallop tissues incubated in FTM at $22^{\circ} \mathrm{C}$ develop aggregations of several hundred large $P$, karlssoni when placed in seawater (McGladdery et al. 1991). Some thraustochytrids appear viable after incubation in FTM (Quick 1972). they could proliferate in seawater and account for this observation.

The prezoosporangia described by McGladdery et al. (1991) differ from those of Perkinsus species in other ways. Successive bipartitioning of the protoplast of the cell as described for Perkinsus spp. (Perkins \& Menzel 1966) was not observed in $P$. karlssoni. Furthermore, the discharge tube of the 'zoosporangium' of $P$. karlssoni was filled with cytoplasm which is unlike other Perkinsus spp. (Perkins \& Menzel 1966, Lester \& Davis 1981, Azevedo et al. 1990). The 'zoosporangia' described by McGladdery et al. (1991) may be equivalent to the hyphal form of $P$. marinus found occasionally in FTM (Ray \& Chandler 1955, Quick 1972) and culture media (La Peyre et al. 1993). Whether this hyphal form is a phase of the life cycle in P. marinus or a contaminant is not clear. Cells with hyphal-like outgrowths, however, are neither the usual nor the dominant form of the parasite and failure to observe the typical prezoosporangia of Perkinsus casts doubt on the diagnosis of McGladdery et al. (1991).

Perkinsus spp. release zoospores from the prezoosporangia (developed in FTM) after several days in seawater. The zoospores are biflagellate with filamentous mastigonemes on one side of the anterior flagellum. Whyte et al. (1993a) found that the most efficient method to collect 'zoosporangia' and zoospores included the maceration of the scallop tissue followed by incubation in seawater at $26^{\circ} \mathrm{C}$ for $3 \mathrm{~d}$. We attempted to isolate zoospores of $P$. karlssoni using the same procedure. We placed tissues directly into sterile artificial seawater and biflagellates appeared in our cultures after $4 \mathrm{~d}$. DNA was extracted from these organisms and the small subunit ribosomal DNA (SSU rDNA) amplified by polymerase chain reaction (PCR) (Goggin \& Barker 1993). The product was sequenced using automatic sequencing (Applied Biosystems, Inc.) and the data compared to those held in computer databases. The sequence (1680 bp) was most similar to the SSU rDNA data from Cafeteria roenbergensis (EMBL accession number L27633; Leipe et al. 1994) with differences in 5 positions ( 2 additional, 2 different, 1 missing). Fourteen ambiguous positions in the SSU rDNA data from C. roenbergensis were resolved by our work. These molecular analyses indicate that the biflagellates found in our seawater cultures were members of the genus Cafeteria and were most likely C. roenbergensis.

Cafeteria roenbergensis is a bicosoecid flagellate reported from waters near Denmark, Australia and Hawaii (Fenchel \& Patterson 1988). The cell body of C. roenbergensis measures $4-6 \times 4-4.5 \mu \mathrm{m}$, which is similar in size to that of Perkinsus marinus (4-6 6 2-3 $\mu \mathrm{m})$ and $P$. karlssoni $(5.8 \times 3.2 \mu \mathrm{m})$. C. roenbergensis is a heterokont and has a bilateral array of tubular mastigonemes on the anterior flagellum (5 to $8 \mu \mathrm{m}$ ) and a trailing posterior flagellum (5 to $8 \mu \mathrm{m}$ ) which lacks mastigonemes. The zoospores of $P$. marinus have an anterior flagellum with filamentous mastigonemes $(10$ to $18 \mu \mathrm{m})$ and a posterior, naked flagellum (6 to $10 \mu \mathrm{m}$ ) (Perkins \& Menzel 1966). The zoospores of $P$. karlssoni are also biflagellate (McGladdery et al. 1991), with a posterior flagellum $(2.7$ to $5.4 \mu \mathrm{m})$ of similar length and an anterior flagellum (11.9 to $17.3 \mu \mathrm{m}$ ) that is longer than that of $C$. roenbergensis. It is possible that Whyte et al. (1993a) confused $C$. roenbergensis with $P$. karlssoni zoospores under the light microscope, particularly as they had not incubated tissues in FTM. 
There are other differences between the zoospores of Perkinsus karlssoni and those of other species of Perkinsus. The behaviour of the zoospores of $P$. karlssoni, as described by McGladdery et al. (1991), is not typical of Perkinsus spp. The zoospores of $P$. marinus swim with a jerky motion (Perkins \& Menzel 1966), do not adhere usually to the substrate and live for several hours (F. O. Perkins pers, comm.). Zoospores of $P$. karlssoni, in contrast, remained close and adhered weakly to the bottom and were viable for up to $9 \mathrm{wk}$ at $4^{\circ} \mathrm{C}$ (McGladdery et al. 1991). Interestingly, Cafeteria roenbergensis can swim but usually adhere to the substrate by the posterior flagelium. The zoospores of $P$. karlssoni were also unlike those of other species of Perkinsus (Perkins 1988, 1991) because they lacked an apical complex, mastigonemes on the anterior flagellum and a large cylindrical inclusion in each kinetosome lumen (McGladdery et al. 1991).

Apparently, the life cycle of Perkinsus karlssoni comprises several unrelated organisms. It is not likely that the differences observed between $P$. karlssoni and Perkinsus species result from 'ten years of transmission via hatchery manipulated spawning' as postulated by McGladdery et al. (1991). The 'prezoosporangia' and 'zoospores' attributed to P. karlssoni do not belong to the genus Perkinsus. Perhaps the lesions in bay scallops are caused by a Perkinsus sp. and most parasites die. The hepantotype of $P$. karlssoni deposited in the Canadian Museum of Nature (CMNP1990-0027) has 'swirl' lesions and is infected by a coccidian as described by Whyte et al. (1994). Whyte et al. (1994), however, reported no apparent response of the bay scallop to the coccidian. Whether the coccidian causes bay scallops to produce 'swirl' lesions under some conditions is unknown. The agent that causes the bay scallop to produce granulomas needs further investigation to determine its taxonomic affinities. It is not certain that it is a species of Perkinsus and we do not recognise $P$. karlssoni as a species of Perkinsus.

Acknowledgements. We thank Ms Janet Munholland and Ms Colleen Murphy, IMB/NRC, Halifax, Canada, for sequencing Cafeteria roenbergensis and Drs S. M. Bower, R. J. G. Lester. F. O. Perkins and an anonymous reviewer for helpful comments on the manuscript. C.L.G. was supported by a Natural Science and Research Council (NSERC) of Canada International Fellowship.

\section{LITERATURE CITED}

Azevedo C (1989) Fine structure of Perkinsus atlanticus n. sp. (Apicomplexa, Perkinsea) parasite of the clam Ruditapes decussatus from Portugal. J Parasitol 75:627-635

Azevedo C, Corral L, Cachola R (1990) Fine structure of zoosporulation in Perkinsus atlanticus (Apicomplexa: Perkinsea). Parasitology 100:351-358
Dungan CF, Roberson BS (1993) Binding specificities of mono- and polyclonal antibodies to the protozoan oyster pathogen Perkinsus marinus. Dis aquat Org 15 9-22

Fenchel T, Patterson DJ (1988) Cafeteria roenbergensis nov gen., nov. sp., a heterotrophic microflagellate from marine plankton. Mar microb Food Webs 3:9-19

Goggin CL, Barker SC (1993) Phylogenetic position of the genus Perkinsus (Protista, Apicomplexa) based on the small subunit ribosomal RNA. Mol Biochem Parasitol 60 $65-70$

Goggin CL, Lester RJG (1987) Occurrence of Perkinsus species (Protozoa, Apicomplexa) in bivalves from the Great Barrier Reef. Dis aquat Org 3:113-117

La Peyre JF, Faisal M, Burreson EM (1993) In vitro propagation of the protozoan Perkinsus marinus, a pathogen of the eastern oyster, Crassostrea virginica. J Euk Microbiol 40: $304-310$

Leipe DD, Wainwright $\mathrm{PO}$, Gunderson $\mathrm{JH}$, Porter D, Patterson DJ, Valois F, Himmerich S, Sogin ML (1994) The stramenopiles from a molecular perspective: 16S-like rRNA sequences from Labyrinthuloides minuta and Cafeteria roenbergensis. Phycologia 33:369-377

Lester RJG, Davis GHG (1981) A new Perkinsus species (Apicomplexa, Perkinsea) from the abalone, Haliotis ruber J Invertebr Pathol 37:181-187

Levine ND (1978) Perkinsus gen. n. and other taxa in the protozoan phylum Apicomplexa. J Parasitol 64:549

Mackin JG, Owen HM, Collier A (1950) Preliminary note on the occurrence of a new protistan parasite, Dermocystid ium marinum n. sp. in Crassostrea virginica (Gmelin). Science 111:328-329

McGladdery SE, Bradford BC, Scarratt DJ (1993) Investigations into the transmission of parasites of the bay scallop Argopecten irradians (Lamarck, 1819), during quarantine introduction to Canadian waters. J Shellfish Res 12: $49-58$

McGladdery SE, Cawthorn RJ, Bradford BC (1991) Perkinsus karlssonin sp. (Apicomplexa) in bay scallops Argopecten irradians. Dis aquat Org 10:127-137

Moss ST (1985) An ultrastructural study of taxonomically significant characters of the Thraustochytriales and the Labyrinthulales. Bot J Linn Soc 91:329-357

Perkins FO (1988) Parasite morphology, strategy and evolution. Structure of protistan parasites found in bivalve molluscs. In: Fisher WS (ed) Disease processes in marine bivalve molluscs. Am Fish Soc Spec Publ 18:93-111

Perkins FO (1991) Sporozoa. In: Harrison FW, Corliss JO (eds) Microscopic anatomy of invertebrates, Vol 1. Wiley-Liss, New York, p 261-331

Perkins FO, Menzel RW (1966) Morphological and cultural studies of a motile stage in the life cycle of Dermocystidium marinum. Proc natl Shellfish Ass 56:23-30

Quick JA Jr (1972) Fluid thioglycollate medium assay of Labyrinthomyxa parasites in oysters. Florida Dept of Natural Resources Leaflet Series, Vol 6, Part 4, No 3. Florida Dept of Natural Resources, St Petersburg

Ray SM (1966) A review of the culture method for detecting Dermocystidium marinum, with suggested modifications and precautions. Proc natl Shellfish Ass 54:55-69

Ray SM, Chandler AC (1955) Dermocystidium marinum, a parasite of oysters. Exp Parasitol 4:172-200

Whyte SK, Cawthorn RJ, MacMillan RJ, Despres B (1993a) Isolation and purification of developmental stages of Perkinsus karlssoni (Apicomplexa: Perkinsea), a parasite affecting bay scallops Argopecten irradians. Dis aquat Org 15:199-205 
Whyte SK, Cawthorn RJ, McGladdery SE (1994) Coinfection of bay scallops Argopecten irradians with Perkinsus karlssoni (Apicomplexa, Perkinsea) and an unidentified coccidian parasite. Dis aquat Org 18: $53-62$

Responsible Subject Edıtor: A. K. Sparks, Seattle,

Washington, USA
Whyte SK, Cawthorn RJ, McGladdery SE, MacMillan RE, Montgomery DM (1993b) Cross-transmission studies of Perkinsus karlssoni (Apicomplexa) from bay scallops Argopecten irradians to native Atlantic Canadian shellfish species. Dis aquat Org 17:33-39

Manuscript first received: March 13, 1995

Revised version accepted: September 18, 1995 